\title{
Improving critical thinking skills and scientific attitudes by using comic
}

\author{
Mufida Awalia Putri *, Anti Kolonial Prodjosantoso \\ Universitas Negeri Yogyakarta. Jalan Colombo No. 1, Yogyakarta, 55281, Indonesia \\ * Corresponding Author. E-mail: mufidaawaliaputri@yahoo.com
}

Received: 6 September 2018; Revised: 16 August 2019; Accepted: 20 February 2020

\begin{abstract}
The objective of the study is to identify the fitness and the effectiveness of the comic that has been developed using Guided Inquiry Technique in improving the students' critical thinking skills and scientific attitudes for the learning process of Natural Science. The study itself is a research that has adapted the model proposed by Borg \& Gall. Within the conduct of the study, the limited experiment by means of one-group pre-test and post-test design had been conducted. On the other hand, within the conduct of the operational test, the quasi-experiment design in the form of nonequivalent pre-test post-test control group design had been adopted. The results of the study, thus, show that: (1) the Natural Science comic media has been fit for implementation with the "Very Good" category; and (2) the Natural Science comic media has been active in significantly improving the students' critical thinking skills. The mean score for the critical thinking skills of the students in the control group is 0.74 with the "High" category. In contrast, the mean score for the critical thinking skills of the students in the experimental group is 0.87 with the "High" category. In the same time, it is apparent that the improvement of the scientific attitude between the students in the control group and the students in the experimental group has been significant.
\end{abstract}

Keywords: natural science comic; guided inquiry; critical thinking skills and scientific attitude

How to Cite: Putri, M. A., \& Prodjosantoso, A. K. (2020). Improving critical thinking skills and scientific attitudes by using comic. Psychology, Evaluation, and Technology in Educational Research, 2(2), 69-80. doi:http://dx.doi.org/10.33292/petier.v2i2.13

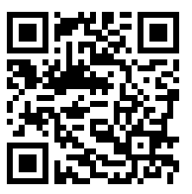

\section{INTRODUCTION}

The current curriculum in Indonesia (K-2013) implies learning should not be result-oriented but, instead, should be process-oriented. Consequently, the assessment within the learning process should be all-encompass-ing and includes the aspects of knowledge, skills and attitude. The Law Number 20 of 2003 on the National Education System Chapter I Article I Verse I states that education should not be oriented toward the individual intelligence but also be oriented toward the aspects of religion, selfcontrol, personality, intelligence, nobility and skills that might be necessary for the individual alone, the society, the nation and the state (Undang-Undang Republik Indonesia nomor 20 tahun 2003 tentang sistem pendidikan nasional, 2003). Therefore, education becomes a step that the government should take in preparing the citizens to be able to compete in the life and to survive in the global competition.

In relation to the elaboration, the students in the Junior High School Degree are the ones in the adolescence period. Adolescence period is a period in which decision-making activities have been increasing (Santrock, 2010). Decision-making activities refer to the high level cognitive process, which include thinking, decision-making, critical thinking, creative thinking and being able to avoid deception and brainwash. Critical thinking, specifically, is highly necessary for the Junior High School students in order to determine good attitudes.

The Process Standards state that learning is directed from the students who have been informed to the students who look for information and that learing sources are not merely the teachers; as a consequence, the teachers only serve as a facilitator. In this regard, the presence of learning media 
becomes highly necessary in order to support the conduct of the teacher's duty so that the students' motivation and understanding might be improved. A learning media will considered good if the learning media is able to facilitate the students' in understanding the given materials. In the same time, a good learning media should be able to facilitate the students in retrieving and understand the given materias easily and enjoyably.

The learning process that the teachers have conducted might not be separated from the learning media. Indeed, many learning media have been developed but most of these learning media have not made the students enjoy the learning process and have not been in accordance to the stage formal operational thinking as well. With regards to the statement, one of the learning media that might be used is comic. Comic as a learning media might be equipped with learning model and students worksheet (Saputro \& Soeharto, 2015). Comic learning media has used to be designed but the one that has been in accordance to 2013 Curriculum with the content that improve the students' critical thinking skills and science attitude by means of Guided Inquiry Model has not been made yet. The use of comic as an enjoyable and flexible learning media is expected to improve the students' critical thinking skills and scientific attitude. With the presence of such a novel learning media, new motivation and enthusiasm might developed in internalizing the contents of the Natural Science subject and also in eliciting the students' potentials so that the students might compte in the international level with their creativity.

Nowadays, comic has been used by both the teachers and the students of Junior High School for the learning process. The comic that has been used coms from highly various quality. With regards to the statement, the findings in the field show that the existing comic has been used as the introductory part for the learning process. However, there are only several teachers who have used comic as part of their learning activities. The use of the comic itself has been emphasized more on the learning process that makes use of Guided Inquiry Model throughout all of the learning activities as the guiding sequence in the learning activities and as the provider of learning materials. At the beginning, comic has been used as an introduction to the discussion activities and the students read the stories that will be discussed in the learning process. Then, the students are directed to criticize the existing problems by answering the questions and performing activities in accordance to the instructions in the comic. Through this sequence, it is expected that the students will be able to criticize the existing problems in the comic so that they will develop their critical thinking skills. The improvement of the critical thinking skills might be viewed from the completion of the exercise test items that have been provided. In addition, through this sequence it is also expected that the students' scientific might be improved.

A study by Prasatia (2014) in six State Junior High Schools that have implemented the 2013 Curriculum in 2013/2014 in the Regency of Sleman show that the students' critical thinking skills have still been low with the average percentage $36.40 \%$. The implication of this finding is that the change of curriculum has not been able to deliver improvement on the students' critical thinking skills. In addition, the facilities in the school have not factually been ready for the implementation of 2013 Curriculum.

With regards to the implementation of the 2013 Curriculum, the State 4 Junior High School Pakem has been one of the most favourite junior high schools in the Province of Yogyakarta Special Region. This state junior high school has been implementing the 2013 Curriculum since the Academic Year 2013/2014. The principal of the junior high school states that the teachers here have better competencies in comparison to the teachers in the other junior high schools. Up to date, the State Junior High School 4 has implemented numerous learning model and has also used numerous learning media such as PowerPoint, OHP, Natural Science Laboratory, Computer Laboratory, three-dimensional media, student textbook and teacher textbook from the government, student textbooks and student worksheets provided by the private publishing companies, and even student modules and student worksheets provided independently by the teachers. Despite these findings, as having been implied previously, comic has never been used as part of learning activities in comparison to other media. For example, $91.00 \%$ respondents from the preliminary study state that the teachers have only used pictorial and colourful media instead of comic during the learning process.

Based on the results of the pre-survey to the Grade VII students, the students agree that the materials of Natural Science should be provided in the form of comic. In the same time, $78.00 \%$ students state their interest to read the Natural Science Comic. Similarly, in the pre-survey activities the 


\section{Psychology, Evaluation, and Technology in Educational Research, 2 (2), 2020, 71}

Mufida Awalia Putri, Anti Kolonial Prodjosantoso

teachers state that the learning activities should be using the syntax that is in accordance to the 2013 Curriculum and entailing the student worksheets.

Furthermore, the results of an interview with the Natural Science teachers for Grade VII state that the materials of Natural Science should be explicitly delivered in accordance to the context of the students' daily life. Within the implementation of 2013 Curriculum for Natural Science Learning Process, the material dept that has been attained is lower because most of the learning period has been devoted for the activities of laboratory practice despite the fact that in terms of content the teaching methods have been various and interesting. The expected learning media is the one that goes in accordance to the psychological development of the students so that the students will like and then will be interested in learning the contents of Natural Science. The scientific attitude that most of the students have internalized is resulted from the habituation of scientific learning and approach; however, there are several students who have been difficult to manage and less persistent. In other words, the persistence of some students has not been maximum. The impact of this situation is that the students' creativity has been lower. Therefore, the students' attitude of discovery and creativity should be improved.

Critical thinking skills are an important element for the junior high school students. As having been proposed by Gunn et al. (2008, p. 175), critical thinking skills are an important element in the education of Science and the teaching of critical thinking skills should be pursued in the senior high school degree and above. By benefitting the critical thinking skills due to the linkage between the curriculum and the implementation of the relevant strategy, the students are taught to investigate problems within a deeper level through a direct manner both consciously and unconsciously. Critical thinking skills are the skills that will not only be useful in the education of Science but also in all disciplines and life paths. As a result, critical thinking skills will not only be necessary for the intellectual development but also for the intellectual creation on the sense of the world.

The selection of Guided Inquiry Model for supporting the critical thinking skills has been supported by the argument from Franco (2013), who states that the Inquiry Model-based teaching practice should be implemented as a valuable journey that will cause the students to develop the actual critical thinking skills and problem-solving skills for the inquirer. Therefore, the use of comic as a learning will be very appropriate as the tool of assistance for the teachers in the teaching process and the students in the learning process. Then, the comic that will be developed in the study refers to a teaching program unit that has peculiar design for the importance of the learning objectives in improving the students' knowledge (critical thinking skills) and attitude (scientific attitude).

The Guided Inquiry Model for improving the critical thinking skills might be achieved if all of the learning syntaxes have been met. Formulating problems and proposing hypotheses might improve the critical thinking indicators of problem formulation and hypothesis proposition. Planning and conducting investigation are one of the syntaxes that might improve the decision-making indicators. Data collection by using relevant tools and procedures for gathering, analysing and interpreting data and also confirming hypotheses by developing description, explanation and models through the existing facts might improve the analysis indicators (assessing relevant information by means of observation results). Last but not the least, elaborating the association between the facts and the explanation and also communicating the procedures and the results of the investigation might improve the conclusion-drawing indicators.

The inquiry-based study refers to the type of research that requires the students to confirm a fact. This type research requires the students to be persistent in for the sake of the success in their research; otherwise, their hypothesis might not be confirmed and thus their research will be meaningless. Therefore, there should be repetitions in order to achieve the success of the research. These activities thus might improve the students' persistence. Through the last syntax of Guided Inquiry Model, namely drawing conclusions based on the facts that have been found, it is expected that the students might improve their scientific attitudes in relation to discovery and creativity.

The use of comic as learning media might increase the students' reading interest so that the students might achieve the optimum level of success. As having been suggested by Kunandar (2013, p. 104), individuals who do not have interest on certain subjects will have difficulties in optimally achieving the learning success; on the contrary, individuals who have interest on certain subjects might be expected to optimally achieve the learning success. Similarly, the results of a study by Negrete $(2013$, p. 207) with regards to the use of comic as learning media show that comic narrative 
has been a good way for reaching into the students with low-level literacy by means of good social message. In the similar tone, the results of the study are expected to confirm that comic as learning media has been quite effective in communicating scientific information. In the same time, comic as learning media might improve the students' good critical thinking skills, creativity and communication. As having been suggested by Weber et al. (2013, p. 4), comic might be benefitted for developing the autonomous values of an individual based on the critical thinking skills and the rights on information as well as personal creativity and also collective and imaginary aspects as part of good communication. This aspect has also been supported by Kilbane and Milman (2013, p. 250), who state that inquiry results in positive matters and the students learn about scientific aspects such as scientific literacy improvement, scientific process habituation, vocabulary knowledge, concept understanding, critical thinking skills and positive attitude toward science. Furthermore, as having been suggested by Majid (2014, pp. 173-174), inquiry learning refers to the sequence of learning activities that emphasize the critical and analytical thinking skills so that inquiry might develop the students' critical thinking skills systematically, logically and critically.

The students are encouraged to search and find independently the answer to the problem that has been questioned. The habituation in inquiry model might improve the students' scientific process but, unfortunately, the male students and the female students pose numerous differences. Thus, the significant differences between the male students and the female students appear because of their scientific attitudes (Pillai, 2012, p. 36). Therefore, there should be a study on the development of Natural Science Comic as learning media with the theme "Heat Around Us" through the Guided Inquiry Model in order to improve the critical thinking skills and the scientific attitude of the junior high school students. The theme "Heat Around Us" is part of the materials under the title "Heat and Its Transfer." Heat is not only contained in the body of human beings, animals and plants but also in the static objects. The contextual materials of "Heat" might be easily learned by means of experiments provided in the comic. With regards to the situation, the objectives of the study are as follows: (1) identifying the fitness of Natural Science Comic with the theme "Heat Around Us" as learning media in improving the critical thinking skills and scientific attitude of Grade VII students in Junior High School degree; and (2) identifying the differences between the implementation of Natural Science Comic as learning media with the theme "Heat Around Us" and the implementation of the student worksheet designed by the teacher in the learning process from the perspective of critical thinking skills and scientific attitude among the Grade VII students in Junior High School degree.

\section{METHOD}

The type of the study was Research and Development (R\&D). Then, the goal of the study was to generate a product in the form of Natural Science Comic as learning media for the Grade VII students in the Junior High School degree for developing the students' critical thinking skills. Thus, the conduct of the study was directed toward developing, validating and testing the effectiveness of the products that had been implemented in the domain of education.

The development model that had been implemented in the study was the development model that had been adapted from Gall et al. (2003, p. 772) with the general procedures that consisted of 10 stages. The 10 stages in the procedure of product test and development were namely: (1) research and information collecting; (2) planning; (3) developing primary form of product; (4) preliminary field testing product; (5) main product revision; (6) main field testing; (7) operational product revision; (8) operational field testing; (9) final product revision; and (10) dissemination and implementation.

The study took place in State Junior High School Pakem 4 from April until May 2015. The samples in the study were the students from Grade VII C and Grade VII D who had been selected without any use of random sampling technique. Then, the development procedures that had been adapted from Borg \& Gall Model might be consulted in Figure 1.

The data gathering methods that had been implemented in the study consisted of observation, interview, questionnaire distribution and written test. On the other hand, the data gathering instruments that had been operated in the study consisted of product validation sheet, observation guidelines on the learning implementation, observation guidelines on the scientific attitude and critical thinking skills test items. 


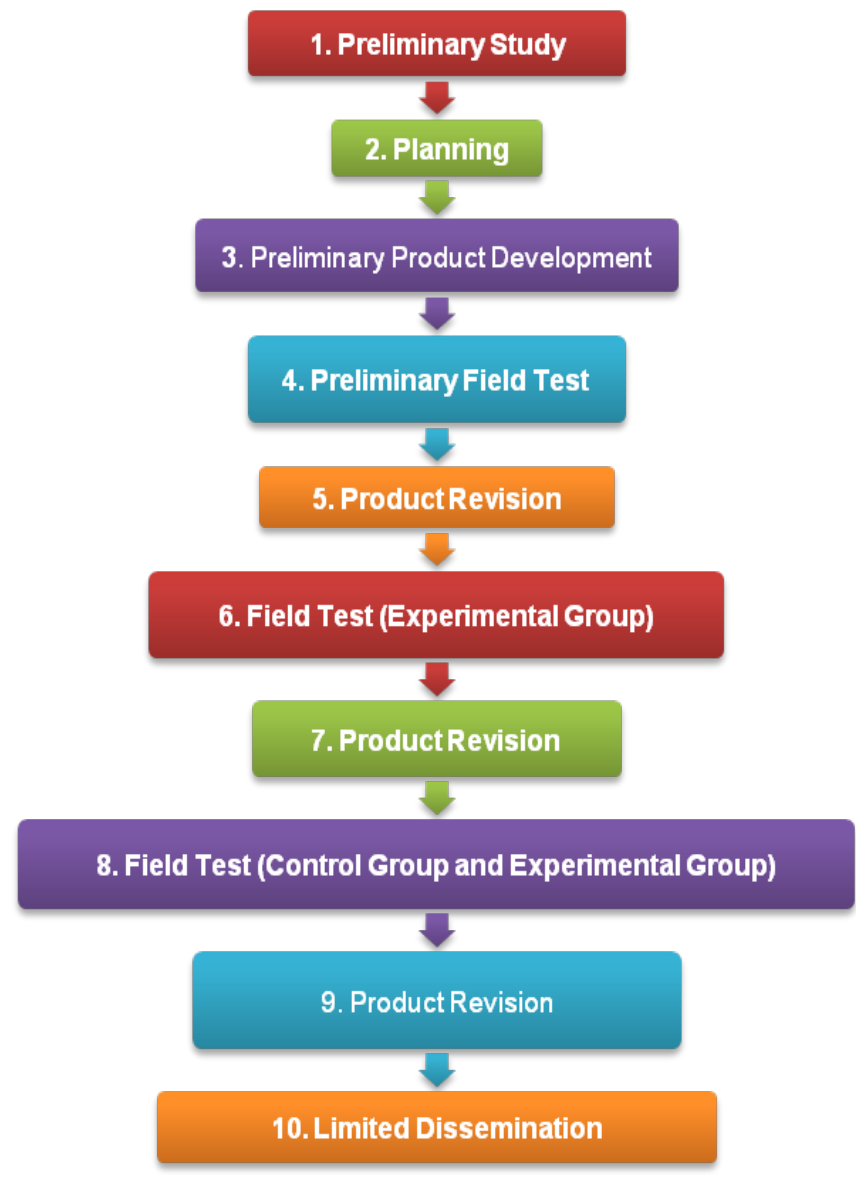

Figure 1. Procedures of Comic Development

After the data had been gathered, the data were analysed by using both of the descriptive and the qualitative analysis. The data on the fitness of the comic were attained from the expert judgment, Natural Science teachers judgment and peer judgment while the data on the students' response were attained from the students during the conduct of the experiment. The product had been considered fit when it met the minimum criteria namely "Good." Furthermore, the quantitative analysis data were attained from the data of the written test and the data of the scientific attitude observation in both the limited experiment and the expanded experiment. The mean score of the assessment data from the written test and from the observation of scientific attitude was converted based on the 5-type scale (Azwar, 2004, p. 123). On the other hand, the data on the students' response was converted based on the 4-type scale (Mardapi, 2008, p. 123). Last but not the least, the gain score was attained based on the calculation toward the data of the students' critical thinking skills by means of Gain Score Formula (Hake, 2007) and its conversion. The results of the Gain Score Conversion might be consulted in Table 1.

Table 1. Category of Gain Score Attainment

\begin{tabular}{cc}
\hline Criteria & Interval \\
\hline High & $\mathrm{g} \geq 0.70$ \\
Moderate & $0.70>\mathrm{g} \geq 0.30$ \\
Low & $\mathrm{g}<0.30$ \\
\hline
\end{tabular}

The implementation of the lesson plan was determined based on the learning process implementation from the observation process. The data that had been attained were analysed and described in order to illustrate the conditions of the subjects. Then, the data analysis was conducted by using the statistical test MANOVA in order to identify the significance on the differences of the critical thinking skills between the control group and the experimental group.

The variable Students' Scientific Attitude was analysed by means of observation and in the form of scientific attitude observation sheet. The size of the improvement on the students' scientific 
observation might be identified by comparing the improvement of the students' scientific attitude in each meeting based on the results in the observation sheet. In this regard, the data analysis was conducted by using the statistical test namely the t-test in the form of two independent sample t-test. The two independent sample t-test was conducted in order to test the differential significance of the scientific attitude mean score between the two groups in the study namely the control group and the experimental group.

\section{RESULTS AND DISCUSSIONS}

The score that has been attained based on the product assessment by the validators is converted by using the 5-type scale. Then, the conversion is used in order to identify the product category. The results of the conversion might be consulted in Table 2.

Table 2. Results of Conversion into 5-Type Scale

\begin{tabular}{ccc}
\hline Mean Score Interval & Predicte & Category \\
\hline $\mathrm{X}>4.00$ & $\mathrm{~A}$ & Very Good \\
$3.30<\mathrm{X} \leq 4.00$ & $\mathrm{~B}$ & Good \\
$.2 .70<\mathrm{X} \leq 3.30$ & $\mathrm{C}$ & Moderate \\
$2.00<\mathrm{X} \leq 2.70$ & $\mathrm{D}$ & Poor \\
$\mathrm{X}<2.00$ & $\mathrm{E}$ & Very Poor \\
\hline
\end{tabular}

The results of the study are in the form of Natural Science Comic Learning Media. Within the product development, the stages that should be gone through are product assessment and product validation. The stage of product validation consisted of material expert judgment and media expert judgment. The validator in the material expert judgment is a lecturer from the Faculty of Mathematics and Natural Science who masters the learning materials of Natural Science, whereas the validator in the media expert judgment is a lecturer from the Faculty of Language and Literature who masters comic and illustration. In addition, in the assessment stage two Natural Science teachers for Junior High School and two colleagues from the Post-Graduate School of Natural Science Education have been involved. The total mean score from the expert judgment, the teacher judgment and the peer judgment in the components of materials might be consulted in Table 3.

Table 3. The Overall Data from the Product Assessment Results by the Material Component Assessor

\begin{tabular}{clcccc}
\hline No. & \multicolumn{1}{c}{ Aspect } & Expert & Teacher & Colleagues & Mean Score \\
\hline 1. & Content relevance & 4.00 & 5.00 & 5.00 & 4.67 \\
2. & Learning Syntax in the Guided Inquiry-Based Comic & 5.00 & 5.00 & 5.00 & 5.00 \\
3. & Eearning Media & 4.00 & 5.00 & 5.00 & 4.67 \\
4. & Development of critical thinking skills & 5.00 & 5.00 & 5.00 & 5.00 \\
5. & Development of scientific attitude & 4.00 & 5.00 & 5.00 & 4.67 \\
6. & Relevance of media to materials & 5.00 & 5.00 & 5.00 & 5.00 \\
7. & Use of media & 4.00 & 5.00 & 5.00 & 4.67 \\
& Mean Score & 4.43 & 5.00 & 5.00 & 4.81 \\
& Total & 31.00 & 35.00 & 35.00 & 33.67 \\
& Category & & \multicolumn{3}{c}{ Very Good } \\
& Predicate & & \multicolumn{4}{c}{ A } \\
\hline
\end{tabular}

Based on the results of the product validation by the material expert, it is found that the preliminary draft of the comic belongs to the "Very Good" criteria with the score 4.43. Then, the results of the assessment by the Natural Science teachers and the colleagues with regards to the components of the Natural Science Comic Learning Media show that the comic belongs to the "Very Good" criteria with the mean score 5. Furthermore, the mean score of all assessors is 4.81 with the "Very Good" category.

Table 4. show the results of the product validation by the media experts, it is found that the preliminary draft of the comic has "Good" criteria with the mean score 4.00. in addition, the results of the assessment by the Natural Science teacher and the colleagues show that the component materials of the comic learning media that has been developed belong to the "Very Good" category with the mean score 4.50 and 4.56 respectively. In overall, the data from the product validation and the media 
component validation show that the comic learning media belongs to the "Very Good" category with the mean score 4.35. Thus, it might be implied that the comic that has been developed is already fit for implementation in the limited experiment.

Table 4. Overall Data on the Product Assessment Results by the Media Componet Assessor

\begin{tabular}{clcccc}
\hline No. & \multicolumn{1}{c}{ Aspect } & Expert & Teacher & Colleagues & Mean Score \\
\hline 1. & Physical layout of the comic & 4.00 & 5.00 & 5.00 & 4.67 \\
2. & Anatomy of the comic & 4.00 & 5.00 & 5.00 & 4.67 \\
3. & Cover & 3.00 & 4.50 & 3.50 & 3.67 \\
4. & Picture quality & 4.00 & 5.00 & 5.00 & 4.67 \\
5. & Story & 5.00 & 5.00 & 5.00 & 5.00 \\
6. & Grammar & 4.00 & 3.50 & 3.50 & 3.67 \\
7. & Language & 4.00 & 5.00 & 5.00 & 4.67 \\
8. & Types of balloon & 4.00 & 3.00 & 4.50 & 3.83 \\
9. & Colour & 4.00 & 4.50 & 4.50 & 4.33 \\
& Mean Score & 4.00 & 4.50 & 4.56 & 4.35 \\
& Total & 36.00 & 40.50 & 41.00 & 39.17 \\
& Category & & \multicolumn{3}{c}{ Very Good } \\
\end{tabular}

The limited experiment is conducted in Grade VII E of State 4 Junior High School Pakem with the total number of respondents 32 students. The data from the learning process in the limited experiment are in the form of the students' response toward the comic learning media that has been developed and the gain score for the students' critical thinking skills. The data of the students' response, which consists of material component and media component, are presented briefly in Table 5.

Table 5. Data of the Students' Response toward the Comic in Grade VII E

\begin{tabular}{clccc}
\hline No. & Components & Mean Score & Predicate & Category \\
\hline 1. & Materi & 3.35 & A & Very Good \\
2. & Media & 3.35 & A & Very Good \\
\hline
\end{tabular}

Based on the mean score of the students' response, it is found that the mean score of the comic that has been developed is 3.35 for both of the material component and the media component. Therefore, it might be concluded that the comic belongs to the "Very Good" category. Furthermore, the critical thinking skills test is conducted in order to measure the students' critical thinking skills mastery. The results of the students' pre-test and post-test activities might be consulted in Table 6 .

Table 6. Results of Grade VII E Students' Pre-Test and Post-Test Activities

\begin{tabular}{ccccc}
\hline Pre-Test Mean Score & Post-Test Mean Score & Mean Score Gap & Gain Score & Category \\
\hline 34.00 & 86.33 & 52.33 & 0.80 & High \\
\hline
\end{tabular}

Based on the results of the Grade VII E students' pre-test and post-test activities, it is found that the students' critical thinking skills have improved. The improvement is apparent from the pre-test mean score, namely 34.00 , to the post-test mean score, namely 86.33 . In addition, it is also found that the gain score of the students is 0.80 and belongs to the "High" category. Then, the pre-test mean score and the post-test mean score that will be put into the differential test should go to the requirement test namely the normality test and the homogeneity test. The conduct of the normality test relies on the use of Kolmogorov-Smirnov Test and the results of the significance test. Based on the results of the normality test, it is found that the data have not been normally distri-buted because the significance value is not higher than 0.05 . On the other hand, the conduct of the homogeneity test relies on the use of the Variance Homogeneity Test which results sig 0.047

The results of the homogeneity test show that the data have not been homogeneous because the significance value has been lower than 0.050 namely 0.047 . Since the data have not met the parametric test requirements, the hypothesis test should be conducted by using the non-parametric statistical test. In terms of non-parametric calculation, the paired data test by means of Wilcoxon test shows that the significance value is 0.000 (Table 7) on the data of the differences between the pre-test mean score and the post-test mean score for the students' critical thinking skills. Since the significance value has been lower than 0.05 , it might be concluded that at the significance rate 0.05 there have been diffe- 
rences between the pre-test mean score and the post-test mean score for the students' critical thinking skills after the implementation of the comic learning media. In other words, it might be further concluded that the comic that has been developed is able to develop the students' critical thinking skills. In relation to the results in Table 7, the histogram on the illustration of the gain score for the students' critical thinking skills pre-test and post-test results might be consulted in Figure 2.

Table 7. Results of Wilcoxon Test

\begin{tabular}{|c|c|c|}
\hline & Test & Asymp. Sig. (2-tailed) \\
\hline \multicolumn{2}{|c|}{ Critical Thinking Skills } & 0.000 \\
\hline \multicolumn{3}{|c|}{100} \\
\hline \multirow{10}{*}{ 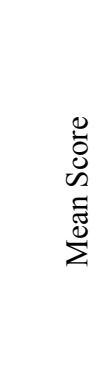 } & 90 & \\
\hline & 80 & \\
\hline & 70 & \\
\hline & 60 & \\
\hline & 50 & \\
\hline & 40 & \\
\hline & 30 & \\
\hline & 20 & \\
\hline & 10 & \\
\hline & 0 & Posttest. \\
\hline
\end{tabular}

Figure 2. The Students' Pre-Test Mean Score and Post-Test Mean Score in the Limited Experiment

The data of the learning activities in the field test consist of the data on the learning activities implementation, the data on the students' response toward the comic learning media, the data on the results of scientific attitude observation and the data on the students' critical thinking skills. Then, the level of lesson plan activities implementation in the field expeirment is $100.00 \%$.

The students' response during the learning process by using the Natural Science Comic learning media might be identified from the questionnaire that has been distributed at the end of the learning process. The data on the students' response consist of material component and media component. The data on the students' response might be consulted in Table 8 .

Table 8. Data on the Students' Response toward the Comic Learning Media in the Operational Field Test

\begin{tabular}{clccc}
\hline No. & Components & Mean Score & Predicate & Category \\
\hline 1. & Materi & 3.41 & A & Very Good \\
2. & Media & 3.36 & A & Very Good \\
\hline
\end{tabular}

Based on the attainment of the students' mean score, it is found that the mean score of the comic that has been deveoped is 3.41 for the material component and 3.36 for the media component. Therefore, it might be concluded that the comic that has been developed belongs to the "Very Good" category.

Within the study, the students' learning results are reviewed from the critical thinking skills. The test on the learning results is administred in order to identify the students' success on the critical thinking skills with the pre-test and the post-test activities. Then, the gain score is calculated and analysed by means of MANOVA. The gain score is used in order to identify the improvement on the students' critical thinking skills from the pre-test activities to the post-test activities. The data on the students' pre-test results and the post-test results with regards to the critical thinking skills might be consulted in Table 9.

In addition, within the study the students' learning results are also reviewed from the competence achievement. The competence achievement test is administered in order to identify the students' success in understanding the learning materials. Then, the students' cognitive learning results are analysed by using the pre-test and the post-test activities. The gain score from the pre-test and the post-test activities in this regard is calculated and analysed by using MANOVA as well. The gain score analysis is intended to identify the learning results on the cognitive aspect or the gap between the post-test activities mean score and the pre-test activities mean score. The data on the competence achievement of the students might be consulted in Table 10. The attainment of the preliminary score and the final score of the students' critical thinking skills between the control group and the experimental group is visually presented in Figure 3. 
Psychology, Evaluation, and Technology in Educational Research, 2 (2), 2020, 77

Mufida Awalia Putri, Anti Kolonial Prodjosantoso

Table 9. Data of the Gain Score from the Critical Thinking Skills in the Operational Field Test

\begin{tabular}{lccccc}
\hline \multicolumn{1}{c}{ Group } & Pre-Test Mean & Post-Test Mean & Gap Mean & Gain Mean & \multirow{2}{*}{ Category } \\
\hline Control & Score & Score & Score & Score & High \\
Experimental & 29.52 & 71.61 & 40.78 & 0.74 & High \\
\hline
\end{tabular}

Table 10. Data of the Gain Score from the Competence Achievement Results in the Field Operational Test

\begin{tabular}{lccccc}
\hline \multirow{2}{*}{ Group } & Pre-Test Mean & Post-Test Mean & Gap Mean & Gain Mean & \multirow{2}{*}{ Category } \\
\hline Control & Score & Score & Score & Score & \\
Experimental & 55.70 & 70.11 & 13.96 & 0.35 & Moderate \\
\hline
\end{tabular}

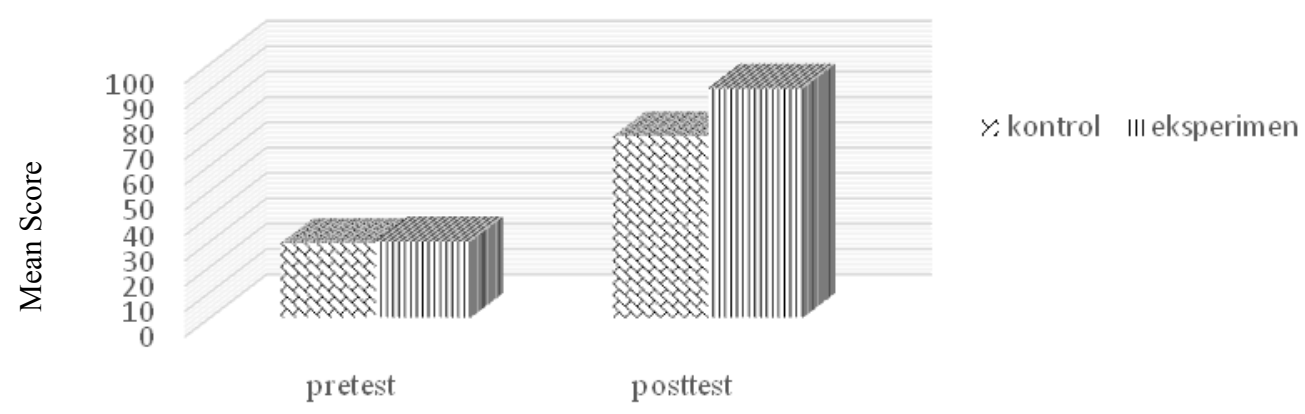

Figure 3. Preliminary Mean Score and Final Mean Score of the Students' Critical Thinking Skills in the Expanded Experiment

On the other hand, the attainment of the preliminary mean score and the final mean score of the students' competence achievement between the control group and the experimental group is visually presented in Figure 4. The achievement of the students' critical thinking skills from the perspective of the preliminary capacity and the scientific learning success is defined by calculating the standard gain score, namely the comparison between the pre-test mean score and the post-test mean score with the gap between the maximum score and the pre-test score.

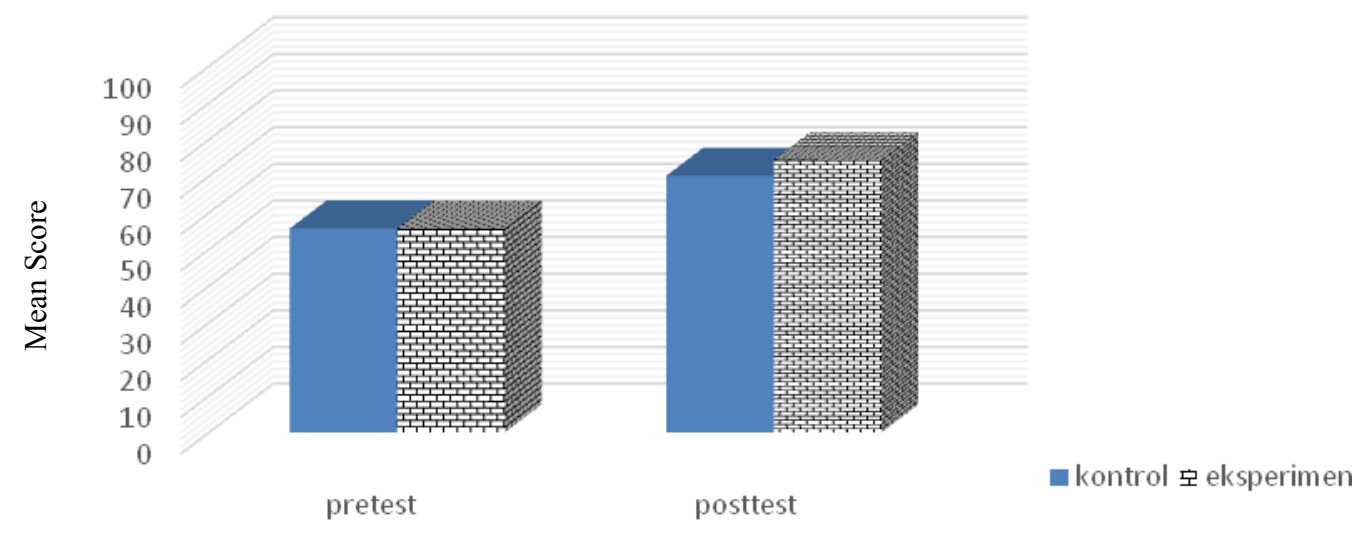

Figure 4. Preliminary Mean Score and Final Mean Score of the Students' Competence Achievement in the Expanded Experiment

The differences on the mean score between the critical thinking skills and the competence achievement are shown by the MANOVA test. Prior to conducting the MANOVA test, the prerequisite test with the degree of significance $0.05(\alpha=5 \%)$ should be conducted first. Then, another assumption that should be met in the MANOVA test is the normality test and the variance homogeneity test. The normality test is conducted by using the Multivariate Normality Test from the mahalanobis value that has been attained from the SPSS calculation. The mahalanobis value itself is $54 \%$, which indicates that the multivariate data have been normally distributed. Then, the chi-square value is 1.38 , which has been the limit of mahalanobis calculation. In overall, there 34 items which chi-square value has been higher than the assigned limit; the percentage of the 34 values then should 
be calculated. Furthermore, the variance-covariance homogeneity is calculated by using the Box Matrices Test.

From the results of the SPSS calculation, it is found tat the Box's M price $=6.309$ with the significance value 0.108 . Since $\alpha=0.05$, then the Box's M price that has been attained is significant because the significance value that has been attained is 0.108 , which is higher than 0.050 . Thereby, the null hypothesis is accepted. In a further sense, it might be implied that the variance/covariance from the dependent variable has been similar (homogenous). Therefore, since the assumption has been met then the analysis toward the MANOVA test results might be proceeded.

At the rate of significance 0.05 and based on the significance value in Wilks' Lamda namely 0.000 , it might be concluded that the alternative hypothesis has been rejected. As a result, there are significance differences on the critical thinking skills and the competence achievement between the students who learn by using the comic learning media and the students who learn by using the conventional learning media.

The scientific attitude assessment is conducted by means of observation and the results of the analysis are analysed by using the Microsoft Excel program. Within the observation, each observer should asssess the two groups. The observation instrument has been assessed by the supervisor lecturer and the validator. Then, the assessment by means fo questionnaire distribution in each meeting namely the first meeting, the second meeting and the third meeting. The data on the results of the observation toward the scientific attitude of the experimental group might be consulted in Table 11.

Table 11. Data from the Results of the Scientific Attitude Observation in the Experimental Group

\begin{tabular}{lcccc}
\hline \multicolumn{1}{c}{ Meeting } & 1 & 2 & 3 & Mean Score \\
\hline Persistence & 3.60 & 4.11 & 4.77 & 4.16 \\
Discovery and Creativity & 3.20 & 2.80 & 4.56 & 3.52 \\
Mean Score & 3.40 & 3.46 & 4.67 & 3.84 \\
\hline
\end{tabular}

The results of the assessment might be traced from the mean score in the first meeting, the second meeting and the third meeting. The data on the results of the observation toward the scientific attitude of the control group in the learning process might be viewed in Table 12. From the three meetings, the mean score for the experimental group is 3,84 while the mean score for the control group 3.66 with "Good" category for both groups. At a glance, the mean score gap between the two groups has not been apparent namely 0.18 .

Table 12. Data on the Results of the Scientific Attitude Observation in the Control Group

\begin{tabular}{lcccr}
\hline \multicolumn{1}{c}{ Meeting } & 1 & 2 & 3 & Mean Score \\
\hline Persistence & 3.59 & 4.09 & 4.58 & 4.09 \\
Discovery and Creativity & 3.08 & 2.78 & 3.86 & 3.24 \\
Mean Score & 3.34 & 3.43 & 4.22 & 3.66 \\
\hline
\end{tabular}

Based on the results of the data analysis by using the SPSS software from the normality test in the rate of significance $5 \%$, it is found that the significance value is 0.200 and 0.161 respectively. Therefore, it might be concluded that the data have been normally distributed. On the contrary, from the results of the variance homogeneity test it is found that the significance value 0.519 . Since the significance value is higher than $\alpha 0.05$, it might be concluded that the data have been homogenous. In addition, the data of the students' scientific attitude are analysed by using the two independent sample t-test and the results of the test show that the sig. (2-tailed) value is 0.001 . Therefore, it might be concluded that there have been differences between the experimental group and the control group with the rate of significance $5 \%$.

As having been implied, there have been significant differences between the control group and the experimental group. Based on the results of the differential test, it might be suggested that the Natural Science Comic Learning Media that has been developed is able to improve the students' critical thinking skills and scientific attitude.

\section{CONCLUSIONS}

Based on the results of the Research and Development efforts, it might be concluded that the Guided Inquiry-Based Natural Science Comic Learning Media has been fit for implementation in the 
learning process. The fitness of the product has been confirmed by the results of the assessment by the media expert with the "Good" category and the results of the assessment by the material expert, the Natural Science teachers and the colleagues with the "Very Good" category. In other words, the Guided Inquiry-Based Natural Science Comic Learning Media has been able to improve the students' critical thinking skills, competence achievement and scientific attitude. The improvement is found in: (1) the difference on the gain score of the critical thinking skills between the students in the control group, namely 0.74 with the "High" category, and the students in the experimental group, namely 0.87 with the "High" category; and (2) the difference on the gain score of the scientific attitude between the students in the control group, namely 0.35 with the "Moderate" category, and the students in the experimental group, namely 0.52 with the "Moderate" category. In the same time, the statistical test (the MANOVA test) results assert that both of the critical thinking skills and the scientific attitude between the control group and the expermental group have been different significantly. From three meetings, the mean score of the students' critical thinking skills for the experimental group is 3.84 with "Good" category while for the control group is 3.66 with "Good" category as well. In the same time, the scientific attitude is also different significantly between the control group and the experimental group.

With regards to the findings and the discussions within the study, several suggestions on the use of the Natural Science Comic Learning Media might be proposed. First of all, the Guided InquiryBased Natural Science Comic Learning Media which validity and effectiveness have been confirmed might be benefitted as one of the alternative learning media for the Natural Science learning process in the Grade VII students. Then, the Guided Inquiry-Based Comic Learning Media should be used with the sufficient time allocation so that all syntaxes of guided inquiry might be met and the students might gain more deeper experiences with the activities in the comic. Next, the teachers should perform the experiments in the comic first so that they might anticipate the mismatch between the experiments in the comic and the experiments in the real life; in the same time, the teachers might also provide several explanations so that misconception among the students might be avoided. Last but not the least, the product that has been resulted in the study, namely the Guided Inquiry-Based Comic Learning Media, might serve as a matter of reference in developing similar comics as learning media with different theme.

\section{REFERENCES}

Azwar, S. (2004). Metode penelitian. Pustaka Pelajar.

Franco, Y. (2013). Building a community of inquirers in your classroom: Learning from our global colleagues. Electronic Journal of Science Education, 17(4). https://ejse.southwestern.edu/article/view/12080

Gall, M. D., Gall, J. P., Borg, W. R. D., \& Gall, J. P. (2003). Educational research: An introduction (7th ed.). Pearson Education Inc.

Gunn, T. M., Grigg, L. M., \& Pomahac, G. A. (2008). Critical thinking in science education: Can bioethical issues and questioning strategies increase scientific understandings? The Journal of Educational Thought (JET)/Revue de La Pensée Educative, 42(2), 165-183. https://journalhosting.ucalgary.ca/index.php/jet/article/view/52463

Hake, R. R. (2007). Design-based research in physics education: A review. In A. E. Kelly, R. A. Lesh, \& J. Y. Baek (Eds.), Handbook of Design Research Methods in Education (p. 16). https://doi.org/10.4324/9781315759593-42

Kilbane, C. R., \& Milman, N. B. (2013). Teaching models: Designing instruction for 21st century learners. Pearson Higher Ed.

Kunandar, K. (2013). Penilaian autentik (Penilaian hasil belajar peserta didik berdasarkan Kurikulum 2013). Rajawali Pers.

Majid, A. (2014). Pembelajaran tematik terpadu. Remaja Rosda Karya.

Mardapi, D. (2008). Teknik penyusunan instrumen tes dan nontes. Mitrs Cendikia Offset.

Negrete, A. (2013). Constructing a comic to communicate scientific information about sustainable development and natural resources in Mexico. Procedia - Social and Behavioral Sciences, 103, 
200-209. https://doi.org/10.1016/j.sbspro.2013.10.327

Pillai, K. (2012). An analytical study on scientific attitude of higher secondary school students in Virudhunagar district. International Journal of Teacher Educational Research, 1(4), 32-37.

Prasatia, R. D. (2014). Studi kesiapan dan kebutuhan sekolah dalam implementasi Kurikulum 2013 dalam mengembangkan keterampilan berpikir kritis peserta didik pada mata pelajaran IPA di Kabupaten Sleman [Universitas Negeri Yogyakarta]. https:/eprints.uny.ac.id/12788/

Undang-Undang Republik Indonesia nomor 20 tahun 2003 tentang sistem pendidikan nasional, Pub. L. No. 20, Undang-Undang Republik Indonesia 26 (2003).

Santrock, J. W. (2010). Adolescence: An introduction. Brown \& Benchmark.

Saputro, H. B., \& Soeharto, S. (2015). Pengembangan media komik berbasis pendidikan karakter pada pembelajaran tematik-integratif kelas IV SD. Jurnal Prima Edukasia, 3(1), 61-72. https://doi.org/10.21831/JPE.V3I1.4065

Weber, K. C., Saldanha, T. C. B., Sousa E Silva, K. K. De, Santos, P. M. M., Souza, D. D. D., \& Arroio, A. (2013). Introducing comics as an alternative scientific narrative in chemistry teaching. Batı Anadolu Ĕ̈itim Bilimleri Dergisi, 4(8), 1-14. https://dergipark.org.tr/en/pub/baebd/issue/3335/46210 